\title{
腰椎椎間板ヘルニアにおける同一椎間再手術例の検討
}

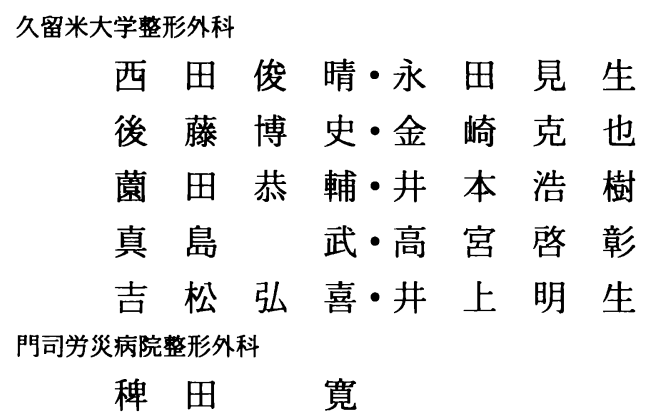

\section{Clinical Results of Multiply Operated Back of Same Level for Lumbar Disk Herniation}

\author{
Toshiharu Nishida, Kensei Nagata, Hiroshi Goto, Katsuya Kanesaki, \\ Kyosuke Sonoda, Hiroki Imoto, Takeshi Mashima, Takaaki Takamiya, \\ Hiroki Yoshimatsu, and Akio Inoue \\ Department of Orthopedic Surgery, Kurume School of Medicine, Fukuoka Japan \\ Hiroshi Hieda \\ Department of Orthopedic Surgery, Moji Rosai Hospital, Kitakyushu Japan
}

\begin{abstract}
Thirty-four patients who had received previous lumbar disk surgery underwent multiply operated back of the same level for lumbar disk herniation. The leading primary causes were adhesion (35\%), relapse (24\%), and degeneration (23\%). The case showing the worst multiply operated back had adheisin that did not improve as much as in the other cases (average improvement 23\%)and the most unstable results. Factors related to unsuccessful multiphy operated back were scar formation, adhesive arachinoditis, nerve root injury at yhe previous operation, multiple operation, and psychogenic factor. Multiply operated back of the same level for lumbar disk herniation was adequately treated by repeat ed discectomy using a microscope. It is important to understand signs, such as symptoms, and take into consideration opinions and portraits that indicate the necessity of surgery in individual cases.
\end{abstract}

Key words : multiply operated back (多回数手術), lumbar disk herniation (腰椎椎間板へルニア), operetive result（手術成績）

\section{はじめに}

腰椎椎間板ヘルニアの手術治療は, LOVE 法など により良好な成績を得ている．しかし，その再発も問 題になることが多く, 諸家の報告では $5 \sim 10 \%$ といわ
れて(る 2$) \sim 4), 8) \sim 10)$.

今回我々は, 腰椎椎間板ヘルニアに対して同一椎間 再手術を行った症例について検討した. 


\section{対象亡症例}

1985 年から 1997 年の間で, 当院における腰椎椎間 板ヘルニアに対するへルニア摘出術は 745 例であり， その内再手術を行ったのは 34 例で全体の $4.5 \%$ であっ た。初回手術時平均年齢は 35 歳，再手術時平均年齢 は 40.5 歳であり, 初回手術より再手術までの期間は 平均 3 年 7 ヶ月であった。また 3 回以上手術を行った あのは 4 例あった.

再手術の方法は, 11 例がへルニア摘出術のみ, 12 例が部分椎弓切除術，8例が全椎弓切除術を行い，そ の内 14 例にはマイクロ使用し，9例には脊椎固定を 併用した。

\section{結果}

retoro spective に原因をみると癒着性病変 35\%, 再脱出 $24 \%$, 変性性変化 $24 \%$ と，これらが原因の多 くを占めていた，(図 1)

また，これら 3 つを再手術前後の症状を，ADL 障 害を除いた 15 点満点の JOA で評価すると, 癒着性 病変は 6.9 点から 8.8 点へ, 再脱出は 7.5 点から 13.4 点へ, 変性性変化は 6.9 点から 11.5 点であり，また平 林法による平均改善率は，癒着性病変は $23 \%$, 再脱 出は $78 \%$ ，変性性変化は $56 \%$ であり，ヘルニア再脱 出の成績が最あ良好であった，瘉着性病変は改善率 9 0\%の例もあったが最も成績が不安定であった（図2）

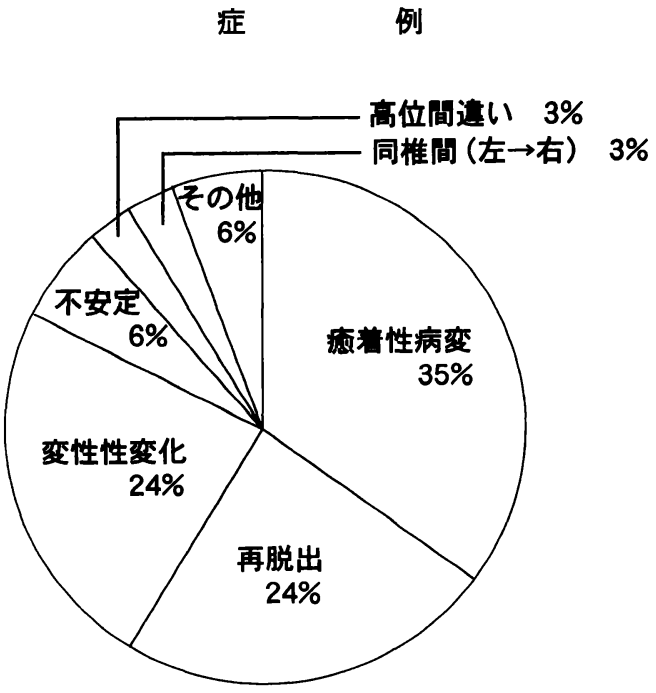

図 1 原因

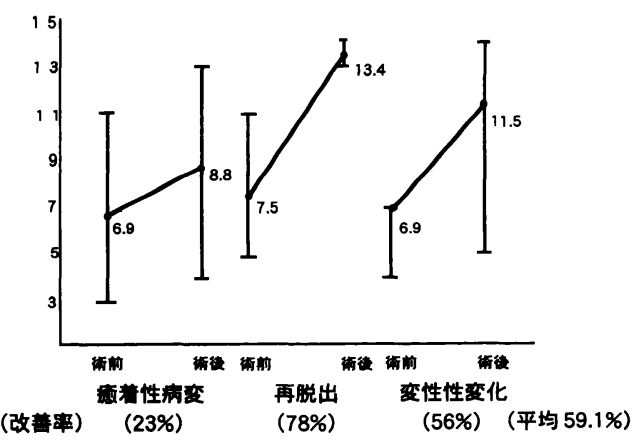

図 $2 \mathrm{JOA}$ 評価（術前 平均 6.9 点, 術後 平均 11.3 点）

<症例 $1>43$ 歳女性, 初回手術より 2 ヶ月後に再 発症した L4/ 5 再発ヘルニア例である。 MRIにて sagital 像, axial 像で L4/ 5 の圧排が見られ，さらに 瘉着と思われるものが enhanceにより明らかになっ た．再手術は, rootへの瘉着, 瘕痕, が著明であり, 部分椎弓切除による椎間板摘出術をマイクロ下に施行 した.JOA は術前 6 点から術後 8 点とほとんど变化 がなかった。（図 3 ）

<症例 $2>23$ 歳男性, 初回手術後より 2 力月後に 再発症した $\mathrm{L} 5 / \mathrm{S} 1$ 再発へルニア例である。 ヘルニア 摘出術の再手術施行するも, 再び 1 ヶ月後, 術前と同 一症状が見られ，MRI，ミエロ，及びCTにて L5/S1 ヘルニアが再び見られた，再々手術では術中 root へ の瘉着、瘕痕は軽度あったが，ほとんどが残存組織で あった．部分椎弓切除による椎間板摘出術をマイクロ 下に施行した。また JOA score は術前 6 点から術後 12 点之改善した.（図 4 )

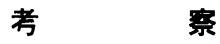

腰椎椎間板へルニアの手術治療は, LOVE 法など により良好な成績を得ている。しかし，その再発む問 題になることが多く，諸家の報告では $5 \sim 10 \%$ と言わ

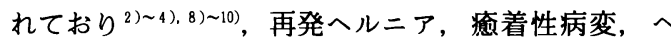
ルニアの取り残し，変性性変化，等種々の原因が考え られる．また諸家の報告による手術成績も様々で1) 10), これらをまとめると, 成績良好因子は, 同一レベルの 明らかな脱出へルニア, 初回手術後一定期間の寛解期 の存在，1レベル障害などである，また，成績不良因 子は, くも膜炎の合併, 癜痕による神経根障害, 3 回 以上の手術, 精神的背景の存在などが挙げられる. 問 題点としては取り残し（不十分な手術）と再発との鑑 

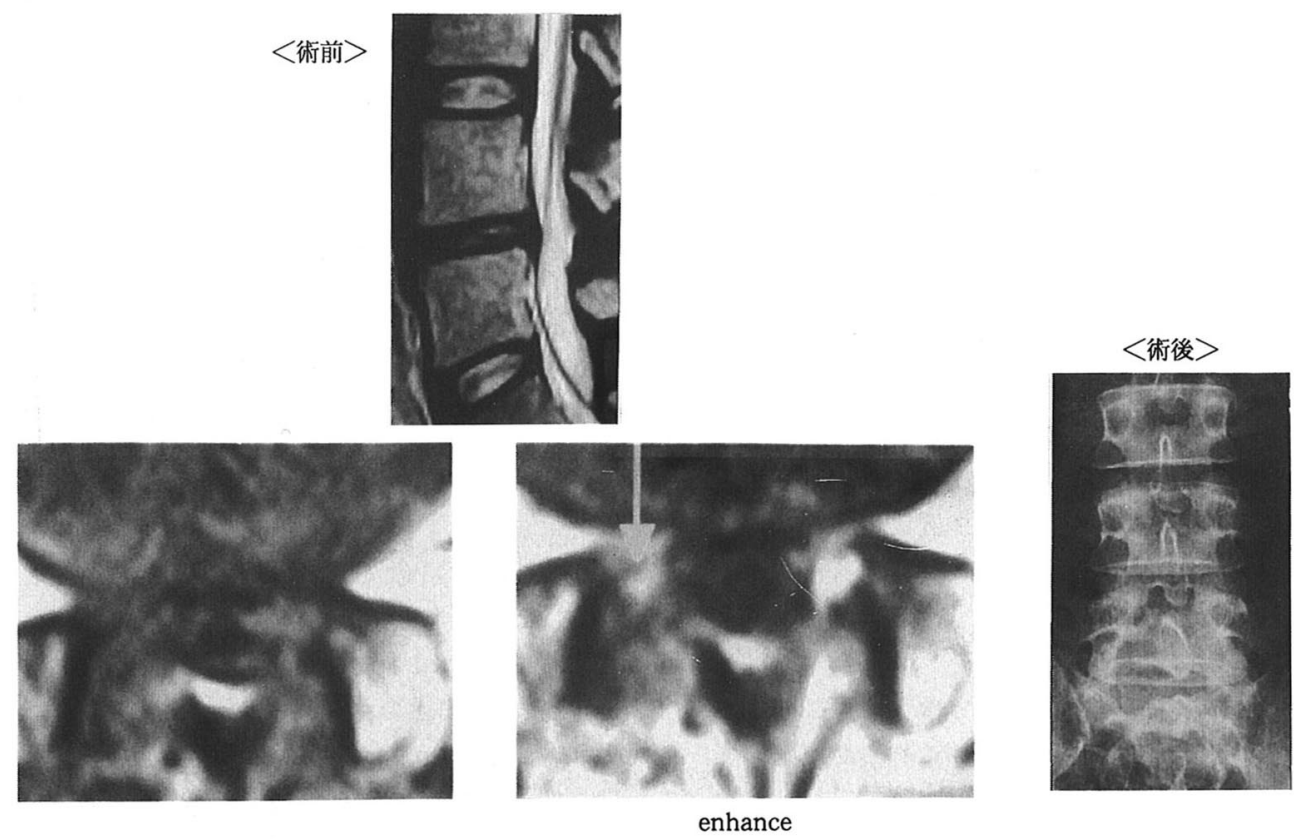

図 3 症例 $1 ： 43$ 歳女性 L 4/5ヘルニア
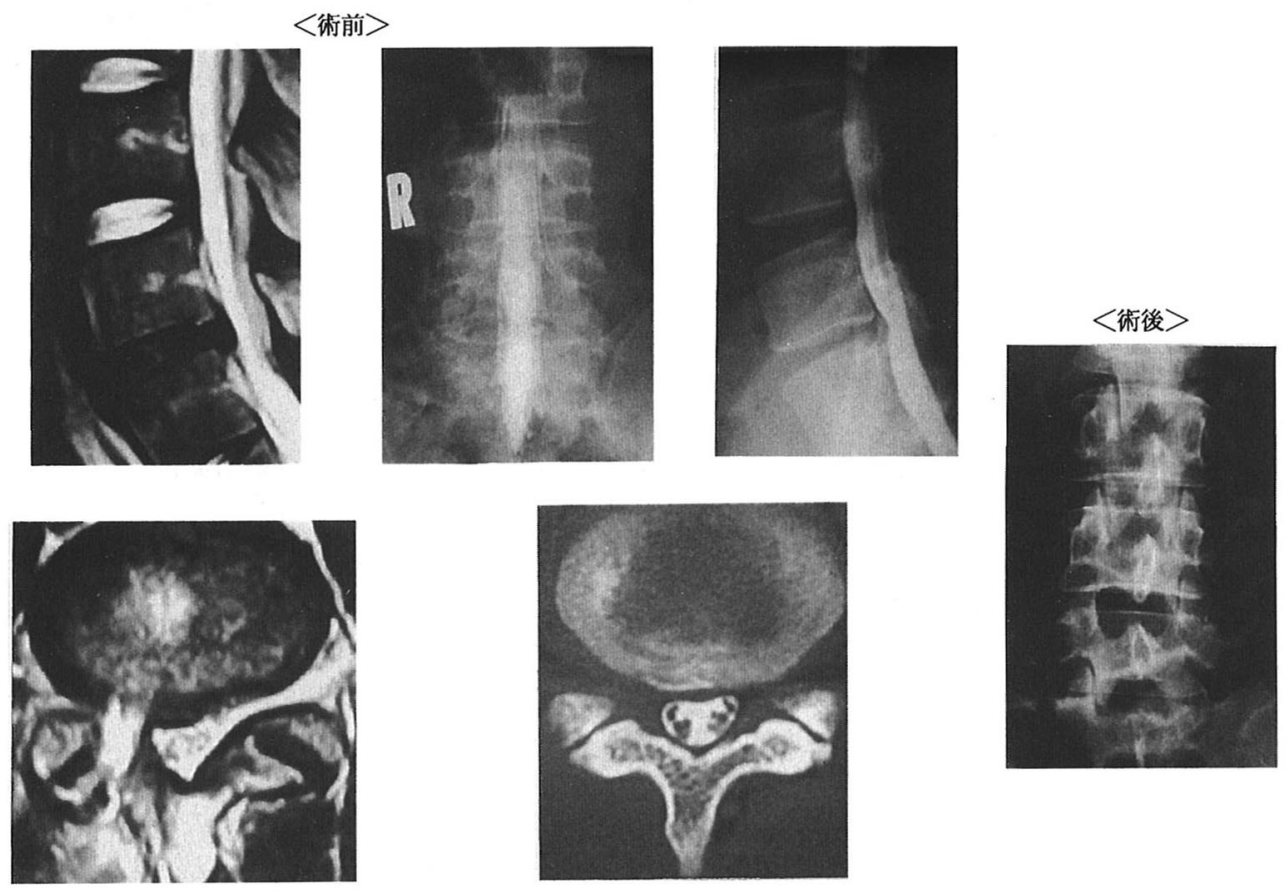

図 4 症例 2:23 歳男性 L 5 / S 1 ヘルニア 
別, 癒着と再脱出との鑑別をどのように判断するのか が挙げられる. 初回手術後, 症状再発の原因は多岐に 及び, 症状, 所見, 各種画像診断を用いた綿密な神経 学的検索による病態把握が重要であると考えられる. また当院井本らの検討 ${ }^{5)}$ であ明らかなように, 手術に 際してはマイク口の使用は必須であり, 神経組織に対 する愛護的操作が大切である.

\section{結語}

当科における腰椎椎間板へルニアに対する同一椎間 再回手術を施行した 34 例ついて検討した。同一椎間 再手術を施行した中で, 癒着性病変 35\%, 再脱出 24 $\%$, 変性性変化 $24 \%$ とこれらが多くを占めていた。 癒着性病変は平均改善率 $23 \%$ と最も悪く, また成績 が不安定であった。 再手術には症状, 所見, 画像など を総合的に判断し個々に応じた手術をすることが大切 であると考えられる。

\section{参考 文 献}

1) Baba H. et al.: Revision surgery for Iumbar disc herniation. An analysis of 45 patients. Int Orthop. 19 : 98-102, 1995.
2）淵上泰敬ほか：腰椎椎間板ヘルニア再手術例の検討. 西日本脊椎研究会誌 24 巻 : 30-32 頁, 1998 .

3) Herron L : Recurrent Iumbar disc herniation, resuits of repeat laminectomy and discectomy. J Spinal Disord. $7: 161-166,1994$.

4）原真一ほか：腰椎椎間板ヘルニアの同一部位再発例に おける Love 法の治療成績. 西日本脊椎研究会誌 24 巻: 25-28, 1998.

5）井本浩樹ほか：腰椎椎間板へルニアの多数回手術の検 討. 西日本脊椎研究会誌 24 巻 : 33-6 頁, 1998 .

6) Jonsson B, et al. : Repeat decompression of Iumbar nerve roots. A prospective two-year evaluation. J Bone Joint Surg. Br. $75: 894-897,1993$.

7）西村行政ほか：腰椎椎間板ヘルニアに対し後方椎間板 切除後同一椎間再手術例の検討. 西日本脊椎研究会誌 24 巻 : 20-24 頁, 1998 .

8）猿渡康雄ほか：腰椎椎間板へルニアに対する Love 法 の術後 10 年以上の長期成績. 日本脊椎外科学会 10 巻 9 頁, 1999.

9）辻陽雄ほか：腰部椎間板障害再手術の原因と対策，80 例の検討加ら. 整形外科 MOOK 11 巻：266-285 頁, 1979.

10）米倉徹ほか: 腰椎椎間板へルニア再手術例の検討, 初 回手術後 10 年以上経過例について. 日本脊椎外科学会 誌 10 巻 26 頁, 1999 . 